\title{
Retention of Lecturers at the University of Zambia from 1990 to 2010
}

\author{
Rosemary Mulenga, Henry Msango
}

\begin{abstract}
This article looks at the approaches the University of Zambia used in retaining lecturers during the period 1990 to 2010. The aim of the study was to establish the reasons why lecturers opted to stay at the University in spite of poor working conditions and peer pressure from their colleagues who left for greener pastures. The study also determined the motivating factors to remain or stay at the institution for those lecturers who opted to work there. In this study, both quantitative and qualitative designs were used. The mixed method approach incorporated different types of data to help in answering the research questions. Quantitative data was analysed using statistical package for social sciences while qualitative data was analysed using common responses from themes. Research findings show that lecturers left the University of Zambia because of poor economic conditions in the country among other factors. The conclusion of the study showed that the University should identify critical employees and understand their needs with regards to career, family, education and community. It is recommended that management should improve their managerial skills. Salaries, fringe benefits and pensions should be paid on time. them.
\end{abstract}

Keywords: Retention, turnover, motivation, university.

\section{BACKGROUND}

The University of Zambia is the first national University in the country. It was established in 1966. It is located in Lusaka which is the capital city. It has a student population of more than 25,000, (Kantini, 2015). The actual staffing levels at the University of Zambia as at October 31, 2012 were 2017. There were 6 principal officers: 5 males and 1 female. There were also 17 officers in Senior Management: 14 were males and 3 were females. There were 658 members of the academic staff of whom 543 were males and 115 were females. The Professional, Administrative and Technical staff were 320: 215 were males and 105 females. The population of the ancillary workers was 1016: 616 were males and 400 females, (UNZA: 2012). The University has over 157 degree and postgraduate degree programmes. At the time of writing this article, it had nine schools (MOE, 2008).

In the 1990's, Zambia experienced a significant decline in the level of investment in the educational sector due to fiscal problems arising from economic recession, structural adjustment programme and global economic restructuring, (Kelly, 2006). The economy of the country was poor and the Government invited foreign donors such as the International Monetary Fund (I.M.F.) and the World Bank to come and help revamp the economy. The country could not keep the pressure with external debt payments. This forced the Government to cut down on the rapid rate of human resource development that occurred after independence in the 1960's. According to Lungu (2004), a wage freeze was imposed in 2003 by the Government on all its workers. This frustrated many academicians and they started looking for ways to leave the University. Simutanyi $(2006,8)$ highlighted that social, health and education expenditure were also reduced, affecting mostly working people. This meant reduction in government grants which were given to the University and hence, payments of salaries to the academic staff at the institution were also affected. Hawkins (1991) adds that it was the workingclass that bore almost all costs of these IMF reforms. The economy became unbearable and many lecturers left the country for other alternative employers who offered more competitive conditions of service which were not offered by the University. Ministry of Education (2008:6) reported that between 1984 and 1994, the University of Zambia lost over 230 of its lecturers, 161 of them being $\mathrm{PhD}$ holders with considerable degree of seniority. This mass exodus was not only alarming but had also been a big loss to the University. The education sector was affected when individuals, private companies and organizations joined in the offering of university education (Kelly, 2006). Some lectures got fascinated to the attractive conditions that these private organisations offered and joined them as academic staff members while others went outside the county. 
The remaining lecturers attended to large numbers of classes in spite of poor condition of service. They valued work more than incentives. Some did consultative works, while others did farming. They were innovative and came up with businesses in order to raise money. Those who felt frustrated left the University to neighbouring countries or America and Europe. Chapman (1994:9) reports that this has led to a lot of employees leaving the profession or the country to jobs that are more motivating. The loss of some academic staff puts research which is critical to the country's development, the academic health of a university and has put a question mark over the ability of the institution to provide service and advice to the people of Zambia. The county will continue to have losses if the conditions of service remain poor at the institution (MOE, 2008).

Bachelor of Education in Mathematics and Science (BEDMAS) in the year 2000 was introduced at the University. It offered a three year programme to those teachers who had a diploma in Mathematics and Science and the content was reduced to that of a teacher. Distance Education was also introduced at the University. All these programmes were aimed at raising income to run the University.

\section{Dimensions of research problem on retention}

The economic condition prevailing in a country may affect lecturers' decision to leave or stay in a university. According to (Blau and Khan, 1981), lecturers who have stayed longer are most likely not to leave. Those who go away migrate to other places where salaries are attractive. When there are no advancement opportunities in the job, lecturers may change to go to places where there are more chances to go for further studies.

Poor retention would also be looked at from the extraneous factors point of view. Some lecturers leave the institution because the employment levels are too high. Their skills are on high demand and hence they easily join other institutions which have attractive working conditions. The political appointments done by the government may contribute to turnover. Some lecturers are given appointments, leaving gaps in the learning institutions. Lecturers who own property, land or other assets opt not to go because they are occupied with their own business and pretend all is well at the University.

\section{Positive effects of retention}

When professionals leave for greener pastures, they leave a gap. Those who remain are easily identified as being loyal and hard working and have chances of being promoted. Sometimes they even get an opportunity to go for further studies because they are few at their place of work (Kellough and Osuna, (1995).

\section{Negative effects of retention}

The poor economic condition in Zambia in the early 1990's made the country to lose a lot of qualified staff to other institutions within and abroad. Lecturers left for these places because their conditions of service were better than the ones obtaining at the University of Zambia. The lecturers in these countries received better remunerations than those who worked within the country. Everson (2004:5) states "the escape route from the mass poverty now endemic in most African countries is improved income."

Sometimes lecturers resorted to strike actions due to dissatisfaction. The time lost for teaching during these strikes was never regained. Those who graduated during this time could have come out half baked. This is supported by Kelly (2006:103) who says: in later years, there was a loss of time, continuity, trust and international credibility through regular and prolonged closures and disturbances. It became expensive for the Government to lose lecturers to other countries after spending a lot of money on their studies. This became a challenge to the University administration in coming up with attractive rewards to retain lecturers.

\section{THEORETICAL FraMEWORK}

The study was based on the Theory of Work Adjustment and Maslow's Motivation Theory (Dawis, \& Lofquist, 1991). Theory of Work Adjustment suggests that work environment and employees interact to meet each other's requirements and this interaction is called environment-personality correspondence. There was no interaction between the environment and the personality and hence could not achieve the long lasting employment relationship between the employer and the lecturer. 
Maslow, in his Motivation Theory (1954) came up with the motivation theory of hierarchy of needs. He argues that individuals are motivated to satisfy a number of different kinds of needs, some of which are more pressing than others. Until these pressing needs are satisfied, other needs have little effect on an individual's behaviour. As long as somebody has food, water, shelter, he feels sense of belonging, safe and secure and will not see the need to cy for more resources or need to leave instead they will continue building their self esteem with a view to reach their actualisation. Lecturers who remained felt contented because the more students they produced the more their needs were satisfied. They find more happiness in what they produced. Employees are more satisfied by jobs that meet their needs and they can retain such jobs longer when they are satisfied and are performing well (Roessler, 2002).

\section{LiterATURE REVIEW}

It is interesting to note that academic staff retention is a worldwide difficulty, affecting industrialized and developing countries. As Tetty (2006:11) pointed out: In the United States, 7.7 per cent of all full time academic staff left the institutions for other places within one academic year. This does not differ from what obtained in Zambia in the 1990's to 2010 when many lecturers flocked to countries in the region, America and Europe to take up positions because of favourable working conditions. For the Governments which hire trained personnel from other countries, professional flight is a benign phenomenon; it makes it possible for them to benefit from the knowledge and skills of people whose training they did not finance (Kyambalesa, 2013). The Government lost a lot of money to educate them but because of poor motivation on the academic staff, they fled to other counties. Brain drain has been acute for poorer countries that lose workers to wealthier countries", (Shah, 2006:1). Many lecturers ended up going to developed countries or countries in the sub-region where their skills were appreciated.

According to the 2001 report of the UN Development Program, in Kenya: it costs about $\$ 10,000$ to $\$ 15,000$ to train a student for four years...it can cost nearly $\$ 40,000$ to educate a physician (ElKhawas, 2004:46). Other reports estimate that it takes US\$60,000 to train a general practitioner and upon migration to the host country, this investment is lost (Ntuli, 2004). This contributed to the poverty of our country because money was lost on the training of lecturers in the University who later left without serving for a long time. The value is likely to have increased dramatically given the increase in educational attainment in the last two to three decades. This is a loss of human capital and a wasted investment in education from the standpoint of the home country. In less than forty years (1970-2008), the African continent has lost about US\$700 billion in capital (Africa Focus, 2011). Furthermore, "there is a loss of potential tax revenue that might have been raised from the income of the emigrant" (Bollard et al, 2008:71). The Government lost tax from the people who migrated abroad. Lecturers decided to go to institutions within and outside the county where motivation was high. Below is a table showing were lecturers migrated to:

\section{MIGRATIONS BY DESTINATIONS}

\begin{tabular}{lcc}
\hline DESTINATION & NUMBER OF LECTURERS & PERCENTAGES \\
\hline Europe & 25 & $8 \%$ \\
\hline Within Zambia & 80 & $27 \%$ \\
\hline South Africa & 119 & $40 \%$ \\
\hline West Africa & 3 & $1 \%$ \\
\hline East Africa & 5 & $2 \%$ \\
\hline America & 36 & $12 \%$ \\
\hline Asia & 2 & $1 \%$ \\
\hline unknown countries & 26 & $100 \%$ \\
\hline Total & 296 & $9 \%$ \\
\hline
\end{tabular}

(Source : Dr Lemba 2015) 


\section{METHODOLOGY}

A mixed method approach was used. According to Hayati, Karami \& Slee (2006:193), research project that employs both quantitative and qualitative techniques can be said to be using a mixed method approach. This approach incorporates different types of data to help in better answering the research questions. It has been suggested that a mixed method approach is best suited to exploratory research. This type of research was preferred because it added to the reliability of outcomes as the quantitative data is supported by qualitative data.

\section{Presentation of ReSEarch Findings}

\section{(a) Recruitment}

Evidence from the findings suggests that recruitment practices strongly influence turnover. Considerable findings from this research show that presenting applicants with a realistic job preview during the recruitment process has a positive effect on the retention of the newly recruited academic staff. Some administrators (2015) stated that a realistic job preview presents accurate information about the positive characteristics and potential challenges associated the job. Clear details about performance expectations and the University's performance management processes are given to the new lecturers so that they decide whether to remain at the institution or leave. Once this is done, it helps lecturers adjust easily to their new work environment.

\section{(b) Selection}

How managers at the University handle the selection process also influences turnover. Life experiences associated with people who stay may include the time they spent on the previous jobs, education experiences, involvement and leadership in career-related clubs and institutions, and early work experiences.

Some respondents (2015) revealed that to better manage retention, the University, like many other institutions, is beginning to assess the fitness of the new lecturer with the job and institution during the selection process.

\section{Socialization}

For the University, the findings from the respondents (2015) revealed that turnover rates are often high among new lecturers'. The participants revealed that this situation is particularly troubling because the University may have invested a lot in recruitment, selection, and training. High turnover prevents the University from benefiting from lecturers they invested in. This research discovered, through the findings that socialization practices can help new lecturers to remain in the University.

\section{Training and development}

Training may make lecturers marketable and thus increase the ease with which they can be recruited by rival institutions. Some participants (2015) added that training and development opportunities promote retention by keeping current employees satisfied and well-positioned for future growth of the University. People in certain jobs that require constant updating of skills, for example, information technology, might leave if they have no options for strengthening their skills.

\section{Compensation and rewards}

The rewards offered by the University play a critical role in motivation of lecturers. Some respondents (2015) warned that to fail to offer competitive rewards may put the University at a disadvantage for attracting and retaining lecturers. It was revealed that pay levels and pay satisfaction are only modest predictors of people's turnover decisions and hence there was a need to carefully consider how to use rewards to retain employees.

In weighing the compensation and rewards strategies, the findings show that it is important to keep in mind that employees are concerned with the fairness of the outcomes of reward allocation decisions and the processes by which reward decisions are made and communicated. Reward allocation processes that are seen as fair promote satisfaction and hence retention in the institution.

\section{Supervision}

It is a common saying that "People leave because of bad bosses." This research supports this claims from lecturers interviewed (2015) that "the quality of lecturers' relationships with their supervisors 
contributes to turnover." Evidence also suggests that a lecturer's satisfaction with his or her supervisor, the quality of the exchanges between them, and the fair treatment by the supervisor is related to retention. The study found that fair treatment by the supervisor was more important than the distribution of outcomes in predicting turnover.

\section{Employee engagement}

The research also revealed that strengthening employee engagement at the university also helps to retain talented lecturers. The findings of this study are that engaged lecturers are satisfied with their jobs, enjoy their work and the institution. The lecturers believed that employers value their contribution to the institution. Some respondents (2015) showed that highly engaged employees were five times less likely to quit than employees who were not engaged.

\section{DiscuSSION OF FINDINGS}

A good number of respondents indicated that one of the approaches used by the University in retaining its lecturers is through motivation. A "good manager" is one who helps talented people find satisfaction in their work. Satisfaction is important to every academic staff and will determine whether they would leave or stay in the University. One of the responsibilities of the administrator is to see to it that the academic staff is working efficiently in a good environment and producing the desired goals for the organisation. This is in line with what other scholars have stated; specifically the administrator creates performance in each employee by speeding up the reaction between the employee's talents and the company's goals, and between the employee's talents and the customer's needs (Buckingham and Coffman, 1999).

Contrary to expectations, this research indicates that money is not even in the top five reasons lecturers give when asked why they are leaving an institution. The way a university distributes money indicates what management really wants. This is the same conclusion Herman (1999) made concerning why employees choose to stay in an institution. He asserts that whether an institution truly pays for performance; incentive plans indicate service and an institution that pays and supports employee development will generously pay for academic and training courses. Salary and benefits tend to attract people to organizations, but are not usually the reasons employees leave.

Strong relationships at work are key to retaining people in an organization. Most individuals want and need colleagues to think, work and recreate with. In fact, this is in line with the research done by O'Malley, (2000) which shows that co-worker support and acknowledgement is key to retaining their technical talent. The study found that some lecturers depend on the workplace as a primary source of social relationships.

\section{Satisfaction in One's Position}

One important aspect worth considering in the motivation of employees is job satisfaction. It describes how contented lecturers are with their work. It is believed that what motivates the academic staff is not necessarily being well paid. When Lecturers are given the independence and allowed to sort out their work, they will feel responsible for what they do and find pleasure in it. Satisfaction in one's position has been widely viewed as an indicator of whether one will seek employment elsewhere within a relatively short period of time. Factors that affected employees' satisfaction include rewards, recognition, task identity, feedback, number of positions held at the company, and age.

A study carried out by Colin and Stenland (1990:319) revealed: a salary alone and other material payment do not automatically lead to excellent performance or high production, citing countries like Canada and Japan where there is a high rate of teacher turn over and attrition rate despite handsome monetary remuneration and other comfortable conditions. Therefore, it is important to motivate staff members beyond the salary because production will increase.

\section{Conclusion}

Effective managing retention at the University is important. Keeping valued lecturers takes a wider investigation and awareness that strategic practices should be followed in the motivation of the academic staff. It is easier to hire lecturers when there is a vacancy but it is even more important to keep the old lecturers because they have the knowledge of what is expected of their work. The experienced lecturers keep the University going because they know its culture. They therefore 
contribute to the development of the University by working hard and sacrificing their time towards the wellbeing of the students. Conditions of service in a higher institution should always motivate the academicians in the institutions and there will hence be effective production.

\section{RECOMMENDATIONS}

Improved conditions of service can contribute to lecturers' retention and bring out better performance. The University should pay salaries, gratuity and pension benefits on time. Retired lecturers should be given their dues so that they stop appearing on the payroll unless they continue working at the University after retiring.

Academic staff developments should be accorded priority since possible growth and advancement on the job is a vital motivational factor. Well-designed training programs should be emphasized not just to meet the professional needs of university lecturers but also to enhance the quality of teaching and ensure the retention of competent and dedicated staff. The evidence is clear that well trained and competent teachers provided with relevant conditions tend to be less inclined to leave (Mathis and Jackson, 2000).

Prominence should be given to the provision of research grants. Attending and participating in seminars and conferences should be encouraged to enrich the knowledge and skills of lecturers. According to Mathis and Jackson (2000), the evidence is clear that well trained and competent lecturers provided with relevant conditions tend to be less inclined to leave. The job should be enriched and made more challenging by allowing lecturers to have a chance to take control over the way they do their job and recognize important contributions. Staff development is cardinal in a University because lecturers should be knowledgeable always about their subject content.

The University should be innovative and have its own projects to raise enough funds for the running of the institution. It should stop depending on the Government because when there is an economic crisis, then the University also faces financial challenges to survive through.

The University still uses the traditional method of teaching. It needs enough equipment to be able to start using the technology of the $21^{\text {st }}$ century e,g e-learning, Skype etc.

The Student fees are set according to the political system. Therefore, the Government should stop interfering with the institutional policy especially when it is setting fees for the students because it is these finances that help the University going.

\section{REFERENCES}

Kantini, S.M. (2015). Endogenous Higher Education in Africa: Sustainable Model. Seoul National University: Korea.

Letter from the University of Zambia on staffing levels. (2012).

Ministry of Education (2008). Educating Our Future, National Policy on Education. Institutional Suppliers Limited: Lusaka.

Kelly, M.J. (2006). The Origins and Development of Education in Zambia. From Pre-Colonial Times to 1996. Times Printers: Lusaka.

Dawis, R. V. \& Lofquist, L. H. (1991). Essentials of Person-Environment fit correspondence Couselling. Mineapolis: University of Minesota Press.

Roessler, J.(2002). European Journal of Philosophy vol. 7., Issue 1 Pg. 47-64. April 1991.

Lungu, A. In Global Campaign for Education Policy Briefing. September 27, 2004. Available at http//www.campainforeducation.org

Simutanyi, N. (2006). "Neo-Liberalism and the Relevance of Marxism to Africa: The Case of Zambia." Paper presented at the 3rd International Conference on 'The Works of Karl Marx and the Challenges of the 21st Century', Havana, Cuba, 3-6 May. Accessed November 11, 2012. http://www.nodo50.org/cubasigloXXI/congreso06/conf3_simutanyi.pdf

Hawkins, J. J. 1991. "Understanding the Failure of IMF Reform.” World Development 19 (7):839849. Accessed November 11, 2012 http://www.sciencedirect.com/science/article/pii/ $0305750 X 91901377$

Chapman, D.W. (1994). Reducing Teacher Absenteeism , Attrition: Causes, Consequences and Responses." The Management of Teachers Paris: International Institute for Education Planning. 
Kellough, J.E. and Osuna, W. (1995). Cross-agency comparisons of Quit rates in the Federal Service: Another look at the Evidence. Review of Public Personnel Administration 15 (4): 15 68.

Evenson, R. E. (2004). "Private and Public Values of Higher Education in Developing Countries: Guidelines for Investment." Journal of Higher Education in Africa, vol. 2(1), pp. 151-175.

Tetty, W.J. (2006). Staff Retention in African Universities: Elements of Sustainable Strategy. Canada: Calgary.

Kyambalesa, H. (2012). Emigration of African Professionals: Causes, Effects and Solutions. Lambert Academic Publishing: German.

El-Khawas, M.A. (2004). Brain Drain: Putting Africa between a Rock and a Hard Place. Mediterranean Quarterly 15(4), 37-56.

Bollard, A., McKenzie, D., \& Morten, M. (2010). The Remitting Patterns of African Migrants in the OECD. Journal of African Economies, 19(5), 605-634.

Hayati, D; Karami, E. and Slee, B. (2006) Combining Qualitative and Quantitative Methods in the Measurement of Rural Poverty. Social Indicators Research, v.75, p.361-394.

Buckingham, M. \& Coffman, C. (1999). First, Break all the Rules: What the world's greatest Managers do differently. New York: Simon \& Schuster.

Herman, R. (1992). Employees Retention for Managers and Supervisors. Herman Group: Canada. O’Malley, M.N. (2000). Creating Commitment. Wiley: Canada.

Shah, S. K. and Corley, K. G. (2006), Building Better Theory by Bridging the QuantitativeQualitative Divide. Journal of Management Studies, 43: 1821-1835. doi: 10.1111/j.14676486.2006.00662.x 